\section{Intersections}

Canadian Journal of Music

Revue canadienne de musique
Intersections CANADIAN JOURAL OF MUSIO

\title{
Perspectives on the Late Piano Music of Oskar Morawetz and John Weinzweig
}

\section{Elaine Keillor}

Volume 33, numéro 2, 2013

Musical Perspectives, People, and Places: Essays in Honour of Carl Morey

URI : https://id.erudit.org/iderudit/1032694ar

DOI : https://doi.org/10.7202/1032694ar

Aller au sommaire du numéro

Éditeur(s)

Canadian University Music Society / Société de musique des universités canadiennes

ISSN

1911-0146 (imprimé)

1918-512X (numérique)

Découvrir la revue

Citer cet article

Keillor, E. (2013). Perspectives on the Late Piano Music of Oskar Morawetz and John Weinzweig. Intersections, 33(2), 35-52. https://doi.org/10.7202/1032694ar

\section{Résumé de l'article}

Oskar Morawetz et John Weinzweig étaient des collègues de Carl Morey à la Faculté de musique de l'Université de Toronto. Tout deux ont composé un nombre considérable d'oeuvres pour piano pendant leur carrière de compositeurs. Dans cet article, l'auteur examine les dernières compositions pour piano de Morawetz et Weinzweig en les comparant du point de vue de leur approche de l'instrument et des conséquences musicales de ces approches. Puisque l'approche de Morawetz est basée sur sa connaissance de la musique romantique pour piano, les pianistes ne rencontrent pas dans son oeuvre de grands défis techniques. En comparaison, la musique de Weinzweig amène les pianistes à innover au niveau technique afin de réaliser ses formes sonores liées à une " gestuelle erratique ".
Copyright (C Canadian University Music Society / Société de musique des universités canadiennes, 2013
Ce document est protégé par la loi sur le droit d'auteur. L'utilisation des services d’Érudit (y compris la reproduction) est assujettie à sa politique d'utilisation que vous pouvez consulter en ligne.

https://apropos.erudit.org/fr/usagers/politique-dutilisation/ 


\title{
PERSPECTIVES ON THE LATE PIANO MUSIC OF OSKAR MORAWETZ AND JOHN WEINZWEIG
}

\author{
Elaine Keillor
}

When Carl Morey became a member of the Faculty of Music at the University of Toronto in 1970, two of his colleagues were Oskar Morawetz and John Weinzweig. Both Morawetz (1917-2007) and Weinzweig (1913-2006) taught at the Toronto Conservatory of Music, later named Royal Conservatory of Music, before becoming faculty professors at the University of Toronto in $1952 .{ }^{1}$ All three professors viewed the piano as their main performance instrument. Because Carl Morey pursued research in Canadian music as one of his principal areas of study, this article will look specifically at the piano compositions produced roughly in the last creative decade of the two composers, Morawetz and Weinzweig. ${ }^{2}$ In addition, references will be made to their earlier compositions, and particularly their piano music.

In fact, both composers turned to the piano to produce many of their earliest works and in their later years returned to this instrument frequently. In the case of Morawetz, he wrote Sonata Tragica for piano in 1945, a year after completing his String Quartet No. 1 as a requirement for his Bachelor of Music. Both works won awards in the nationwide competitions sponsored by the Composers, Authors, and Publishers Association of Canada (MacMillan and Beckwith 1975, 157). Weinzweig explored the possibility of using a twelve-tone series as the melodic basis of a composition in a short eighteen-bar piano piece called Spasmodia in 1938 (Gillmor 2011, 278). Once again in the last decade of their compositional production, the piano played a major role. For Morawetz, the piano works written between 1985 and 1995 were Four Contrasting Moods (1986), Five Poetic Sketches (1991), and his unfinished Fantasy for Piano (1995), the last work he endeavoured to write. ${ }^{3}$ For Weinzweig, his last decade

1 In 1952, two other composers joined the Faculty of Music. John Beckwith has written a fascinating autobiographical monograph, Unheard Of: Memories of a Canadian Composer, in which pages 219 to 221 particularly deal with his approach to writing for the piano. Talivaldis Kenins (1919-2008) has also written fine works for piano as discussed in an essay (1994) by Paul Rapoport. Of course, other composers became part of the Faculty of Music prior to 1970 and included Gustav Ciamaga, Lothar Klein, and Godfrey Ridout, none of whom concentrated on piano compositions.

2 Whereas the compositional output of Weinzweig has had two book-length studies (Keillor 1994; and Beckwith and Cherney 2011), the compositions of Morawetz have received little scholarly attention apart from the essay by Sallis (2003) on his Fifth String Quartet.

3 Morawetz also made extensive use of the piano in some collaborative settings during this decade, such as the Sonata No. 3 (1985) for violin and piano, The Weaver (1985) for voice, clarinet, and piano, the Sonata (1985) for trumpet and piano, and the cycle Souvenirs from Childhood (1985, rev. 1987) for medium voice and piano. He also completed the Clarinet Concerto (1989) and the Bassoon Concerto (1994). 
of actively composing (1992-2002) involved the piano even more extensively as a solo instrument. For piano, he created Diversions: 4 Pieces for Young Pianists (1994), 7 Piano Duets (2000), Netscapes (2000), Swing Time (2000), and Playnotes: 8 Pieces for Piano (2002). 4

These composers had several aspects in common along with being pianists and composing for the piano. Both were of Jewish heritage, but experienced that background as children on different continents. Weinzweig was born in Canada, while Morawetz grew up in what is now the Czech Republic. Although both based their adult lives in Toronto where each established his respective career as a composer, Morawetz had had the opportunity to study and be exposed to the rich musical life of Prague, Vienna, and Paris before arriving in Canada. In contrast, Weinzweig had spent time away from Toronto only when he was pursuing graduate studies at the Eastman School of Music in Rochester, New York. Both men considered themselves to be self-taught composers. While at Eastman, Weinzweig discovered compositions by Schoenberg and Berg but could not find a professor who was willing to instruct him in serialism. On the other hand, Morawetz had lived in Vienna, where that approach to composition had begun, but by the mid-193os serialism was not officially taught anywhere and indeed was considered suspect. Through an examination of their late compositions for piano, these commonalities and differences will be seen to have had lasting impact on their respective styles. Although Morawetz was younger than Weinzweig, his last productive decade of composition began earlier than that of Weinzweig. Consequently his approach to pianowriting and particularly his last piano works will be considered here before those of Weinzweig.

\section{Morawetz And the Piano}

Morawetz was born in the castle of Svĕtlà nad Sázavou, near Prague in Czechoslovakia (Morawetz 2014), and his father was a wealthy Jewish businessman who could afford music teachers for the children. The elder son was the first to receive piano instruction, but Oskar was begging for his own lessons by the time he was six. The castle had several keyboard instruments, including a fortepiano. The main instrument that Morawetz used was the late nineteenthcentury grand piano made by the Viennese Friedrich Ehrbar company. 5 His piano teachers before studies at the Prague Conservatoire were Mrs. Ambroz and Mme. Feron. At the Conservatoire he had theoretical instruction and

4 Similarly to Morawetz, Weinzweig used the piano collaboratively in Arctic Shadows (1993) for oboe and piano, Journey out of Night: 14 Visions: A Monodrama (1994) for mezzo and piano, Parodies and Travesties: 8 Dialogues (1995) for soprano, mezzo, and piano, Le Rendez-vous (1995) for soprano, mezzo, baritone and piano, Walking-Talking (1996) for soprano, mezzo, tenor, baritone, and piano, and Interplay (1998) for piccolo, tuba, piano. Other works produced in this decade were Riffs III (1992) for trumpet, Belaria (1992) for violin, viola or cello, Swing Out: Animations and Ruminations on a Double Reed (1995) for bassoon, Divertimento No. 12 (1998) for woodwind quintet and string orchestra, Duo (1999) for two violins, and Prologue to a Tango (2003) for mezzo and four violins. These compositions are discussed in Beckwith and Cherney's Weinzweig (2011), but the late piano works are not.

5 According to the Morawetz website, that piano now resides in the Canadian Embassy in Prague. See "First Lessons," Morawetz 2014. 
studied piano with the well-known pedagogue Karel Hoffmeister (1868-1952). By the time of his graduation from high school, Morawetz knew he wanted to be a concert pianist, but his parents considered music to be only a pastime and hobby. Following his father's wishes, he studied forestry for two years (ibid.).

As the dark clouds of fascism gathered, his father, Richard, realized that it was becoming increasingly dangerous and Jews would be extremely limited in what they could do. Accordingly he changed his mind about Morawetz's goal to be a musician. Possibly he was also swayed by the fact that Georg Szell had recommended Morawetz to be assistant conductor at the Prague Opera, on the basis of his ability to read operatic scores. As a result, Morawetz arrived in Vienna to study music in 1937. There until just after the Anschluss in 1938 Morawetz immersed himself in music and worked with the piano teacher and composer of Jewish heritage Julius Isserlis (1888-1968).

In December 1938, his father sent him to the stimulating musical environment of Paris. Although he mostly absorbed music and worked on his own, he did have some lessons with the piano virtuoso Lazare Lévy (1882-1964) of Jewish heritage. Meanwhile, his parents managed to get out of Czechoslovakia and were in England, where they applied to come to Canada. Morawetz refused to go with them because he wanted to stay in a musical centre like Paris. Unfortunately conditions for non-Parisians became rapidly more difficult. ${ }^{6}$

After trials and tribulations, Morawetz arrived in Toronto on 17 June 1940. Once settled with his parents, he turned his attention to music and began working towards a degree. His theory lessons were with Leo Smith (1881-1952), and he studied piano with Alberto Guerrero (1886-1959). Although in the Cornfield interview materials (2002), Morawetz is critical of the level of music education in Toronto at the time, his opinions could have been more directed to the way musical theory was taught and the absolute lack of any real instruction in composition.

The lessons with Guerrero might have been a revelation for Morawetz. Here was an astounding pedagogue, composer, and concert pianist who lectured on Schoenberg and performed his piano compositions in public. In his monograph on Guerrero, Beckwith included memories of lessons from former students. "For R. Murray Schafer, Guerrero was 'one of the few musicians from whom a student could get ideas beyond music.' Malcolm Troup, like Schafer, records that often the lesson time would be occupied with conversation about literature, painting, or philosophy, aimed at formation of the pupil's intellectual habits" (Beckwith 2006, 120-21). Back in Europe, Morawetz had had teachers who were loath to even accept the works of Bartók, let alone the twelve-tone school.

Apparently Morawetz played a great deal of piano music in addition to operatic and orchestral scores, but according to information given on the website he preferred to become familiar with more music rather than to polish a particular piece for performance ("Music Studies," Morawetz 2014). Possibly

6 For the harrowing details of his adventures in trying to join his parents in Canada, see "Escape," Morawetz 2014. 
under Guerrero's guidance he did prepare a repertoire for public performance, as in Toronto he soon began to give public concerts. The extant programs of his performances from 26 October 1940 until 28 March 1992 give some idea of the breadth of his knowledge of the piano repertoire and his skills as a pianist ("Pianist," Morawetz 2014).7 Not surprisingly, his first piano solos for the Canadian public consisted of Czech works by Suk and Dvořák. He often accompanied violinists and singers, but by 1946 gave his first all piano-solo program, which consisted of compositions by Schubert, Franck, Chopin, Mendelssohn, Brahms, Weber, and Smetana. Beginning in March 1945, he began to perform in radio broadcasts on the Canadian Broadcasting Corporation. The first broadcast was the performance of his own Sonata Tragica. Increasingly his role as a pianist became one of accompanying singers in his own songs. A later appearance as solo pianist was a concert of 7 September 1963, for which he performed only his works for piano.

His solo piano works demand a high level of pianistic skills, as can be observed in the works produced during his last decade of composition. Some elements of these compositions certainly look back to his earlier works, but there are differences. First of all, the completed works do not bear standard classical titles for piano music such as sonata, scherzo, fantasy, prelude, ballade, or suite, as had been the case in his previous piano compositions. Except for the unfinished Fantasy, the titles, Four Contrasting Moods and Five Poetic Sketches invite the performer and the listener to use their imagination to capture the essence of what the musical sounds of each piece might suggest. Also he abandoned the need to recapitulate at least some of the earlier musical material. Instead he allowed his material to grow organically and in the process encourage the listener's imagination to blossom and be led to a new level. With regard to his String Quartet No. 5, Sallis has commented that in this process, Morawetz used a technique akin to Schoenberg's "musical prose" (2003, 16-25).

Contrasting Moods (1986) consists of four piano pieces written as a commission from the Ontario Arts Council. In the score the pieces are given only a number and a speed indication. ${ }^{8}$ Beginning in the early 1980 s, Morawetz appears to have become more diligent about preparing notes to guide performers and the audience about his works. Prior to that time, notes for individual compositions give details about the premiere and if there is any information about the composition, details are pulled from an interview with the composer or possibly written by the performer. An example of the latter is the lengthy note provided for the Fantasy in D minor by Glenn Gould. In Contrasting Moods, the notes appear to be by the composer and give titles to each piece:

The first mood, Meditation, is slow and meditative in character.

7 These programs can be found on the website at oscarmorawetz.com/Tabs/TabMusicians/ Pianist.php.

8 The website provides the opening page of each Mood, along with a portion of the recording by Francine Kay. See "Four Contrasting Moods," Morawetz 2014. 
The second mood, Mysteries of the Wind, is described by the composer as the sound of a fast moving wind which changes several times from loud to soft and almost disappears into silence in the concluding bars.

The third mood, Remembrance Day, starts with a slow, sombre march which changes after four bars into a sad and expressive melodic line. In the middle section, which is written on three (and sometimes even four) staves, the main melody is surrounded above by high pitches and bell sounds, and below, by the colour of a soft Tam Tam ... [A reminiscence of the opening slow march] leads to a powerful dynamic climax of almost orchestral proportions; gradually it dies into a soft, resigned ending.

The nervous, rhythmic vitality of the fourth mood, On the Battlefield, with its steady, fast and obstinate motion paints the scene of a violent battle. It ends with several very percussive dissonant chords in the lowest register of the piano, reminding us of the thunderous, explosive shots from a cannon. (“Four Contrasting Moods," Morawetz 2014)

In the score of the Poetic Sketches, the composer gives a hint for the listener's imagination by placing a descriptive title with each of the five pieces. The first Sketch bears the title "Prelude to a Drama," which, at first glance, might hearken back to his orchestral work of 1956, Overture to a Fairy Tale. However, the piano solo does not hint at what kind of drama might take place, whereas in the orchestral work, the fairy tale reference gives the listener a good sense of what might follow. Morawetz notes, "The tense feeling of the title is expressed in the dramatic rhythms of the opening bars. These are followed by a more expressive lyrical melody which, however, keeps in the accompaniment the strong rhythmic quality. A continuous crescendo leads to the climactic fortissimo statement of the beginning; the tension then subsides quickly and the piece ends pianissimo in the deep register of the piano" ("Five Poetic Sketches," Morawetz 2014).

The second Sketch bears the title "Raindrops." His note for this piece vividly expresses what he wanted the music to convey: "The staccato chords in the first bar expressing the quiet falling of raindrops are followed in the second bar by a soft slowly broken chord picturing the misty atmosphere of a rainy day. These two moods either alternate or appear combined throughout the sketch. Only before the end this melancholic mood is interrupted for a few bars by a bright passage picturing the striking colours of a rainbow, but after a few bars the music returns to the cloudy picture of a rainy day" ("Five Poetic Sketches," Morawetz 2014).

"Storm" is the title for the third Sketch. Perhaps because the musical writing is so descriptive of the impact of a storm, the composer decided only a short note would be required. "The fast motion of the wind-which becomes quite violent towards the end-is the dominant characteristic of this movement" ("Five Poetic Sketches," Morawetz 2014).

The fourth Sketch is "Prayer in Distress." Morawetz writes, "This meditative prayer expresses, as in Psalm 22, the despair of a person who feels that God has forsaken him." In the musical score itself near the end, the composer adds, 
"My God do not forsake me." As he advises the pianist, "In order to express the feeling of this phrase, imagine these words from PSALM 22."

The last Sketch is titled "Olympic Sprinter," with the note, "A trill imitating the sound of a snare drum expresses the anxious tension of the sprinter before he hears the shot of the pistol indicating the start of the run. The run itself is a fast perpetual motion, with special emphasis for the extra added effort before the victorious end" ("Five Poetic Sketches," Morawetz 2014).

In other words, Morawetz explored the impressionistic side of pianism to a greater extent in these last works and expanded his exploration of the sonic possibilities of the piano, a direction that he had begun to incorporate to a certain extent in the Fantasy, Elegy and Toccata (1958). The reference to the snare drum in the note above gives a hint at what he was trying to achieve.

Dating back to at least the Carnival Overture (1946), Morawetz incorporated the practice of introducing a tam-tam in a climactic passage of his orchestral works (MacMillan and Beckwith 1975, 157). In the third Contrasting Mood, Morawetz includes the direction to the pianist of "like a soft tam-tam" as well as the phrase six bars before of "like small, distant bells." The tam-tam directive occurs again in the fourth Sketch. In the third Mood, the note given above indicates that Morawetz associated the tam-tam with death. Donald Mitchell has explored this connection in the scoring of Mahler, who introduced the tam-tam in the Funeral March of his First Symphony's third movement. ${ }^{9}$ Although live performances in Canada of Mahler's symphonies were rare indeed before 1990, Morawetz had probably heard European and American renditions and had certainly studied Mahler's orchestral scores in detail.

From his earliest works for the instrument, Morawetz utilized the breadth of the piano keyboard. Possibly he had become accustomed to utilizing its full expanse while creating keyboard reductions of orchestral scores. Often five and one-half to six octaves of its seven and one-quarter octave span are required in his solo piano pieces. For example, the last system of the Toccata (1958) has the highest B-flat, just one tone below the top key available, and then ends on the lowest $A$ of the keyboard. His interest in this expanse continued in the last piano pieces. Each of the Moods requires at least five and one-half octaves, with the second and third covering six or more. Every one of the five Sketches requires over six octaves.

From his earliest works, Morawetz provided density in his writing for the piano. Usually he obtained it by working contrapuntally with two melodic lines present at the same time. Accompanying these melodies were thick chords, often having a seventh as a basis. In order to clearly direct the pianist on how to interpret this dense texture, Morawetz resorted to three and even four staves to a system. As can be seen above, he pointed out this aspect in the note for the third Mood. Actually he downgraded this visual aspect, as five staves appear there while three and four staves occur in the second Contrasting Mood.

In the Sketches Morawetz uses three or even four staves in every piece except the Olympic Sprinter.

9 See the discussion in Mitchell 1986, 475. 


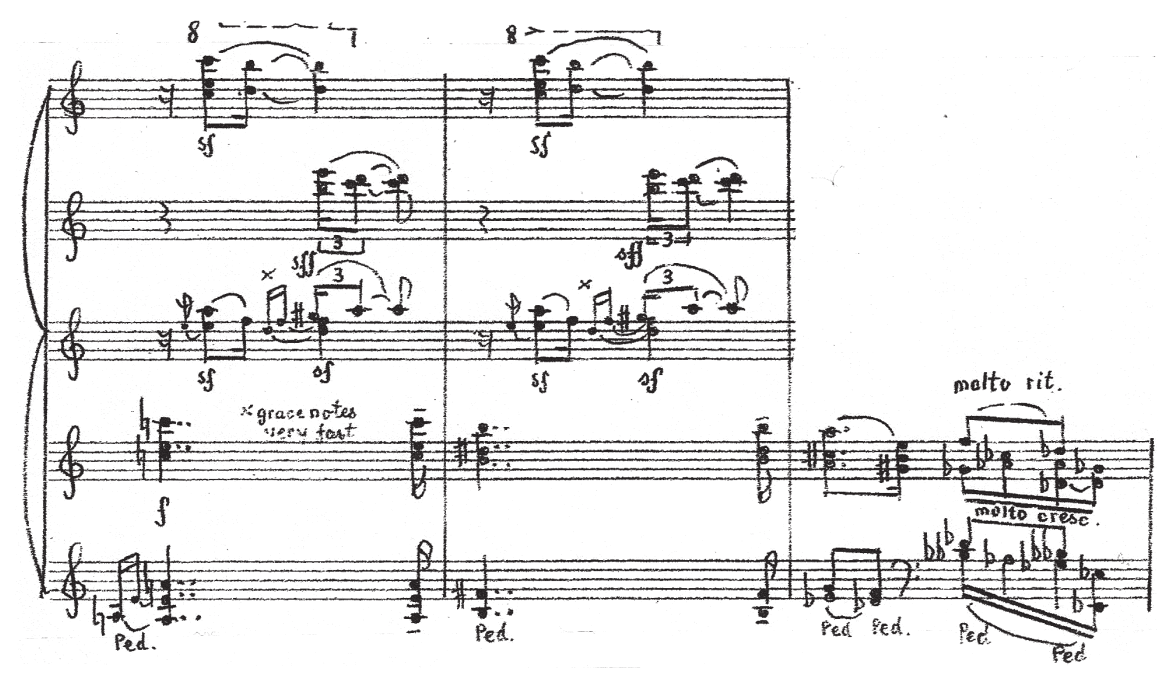

Example 1. Morawetz: Contrasting Mood III, bars 47-49 (with the kind permission of Claudia Morawetz)

Morawetz considered himself a self-trained composer, and only through the exercises required for his Bachelor of Music did he realize that he needed this creative outlet. Consequently he developed his own musical language, based on extended harmonic usage of the late Romantic period. Consequently his pieces always have a tonal centre, but this is not necessarily established by the chords used. In his early Fantasy (1948) he gave the specific key of D-minor in the title. By the early 1950s, (Fantasy on a Hebrew Theme [1951]), Morawetz had dispensed with using key signatures, instead writing in accidentals as required. Tonal centres become established by frequency of use and the movement of melodic lines. For example, in the Prelude of the Suite for Piano (1968), the first bar with the pedalling indicated by Morawetz has eleven pitches of the possible twelve sounding all at once. However, the low F-sharp is reiterated three times. Near the conclusion, the low F-sharp reappears and becomes joined with the fifth above, a C-sharp. To this union is joined the tritone above, a G, the interval with which the piece ends.

Usually the endings of his pieces are not biting but consist of an open fifth, as in (Dance of the Suite, the Elegy and Toccata (1961) or sometimes even a major or minor triad, Fantasy (1961). In the last decade, the final chord generally became more complex, particularly in pieces written after the first Mood, where a C-sharp minor triad appears at the end. If in the later pieces there is a suggestion of a triad, its integrity becomes coloured with adjacent seconds. For example, the third Mood ends with two piled-up fifths, C-sharp, G-sharp, and D-sharp, as well as an A-sharp major triad. In the last bar of the third Poetic Sketch, one can note the open fifth, E and B, that is then coloured with the addition of an $A$ and a seventh $\mathrm{D}$. Prior to that there is the aggregate of a major triad on F-sharp with a minor one on G, suggesting polytonality. All of these combinations rest upon the key centre $\mathrm{E}$ that has gradually been exposed from 


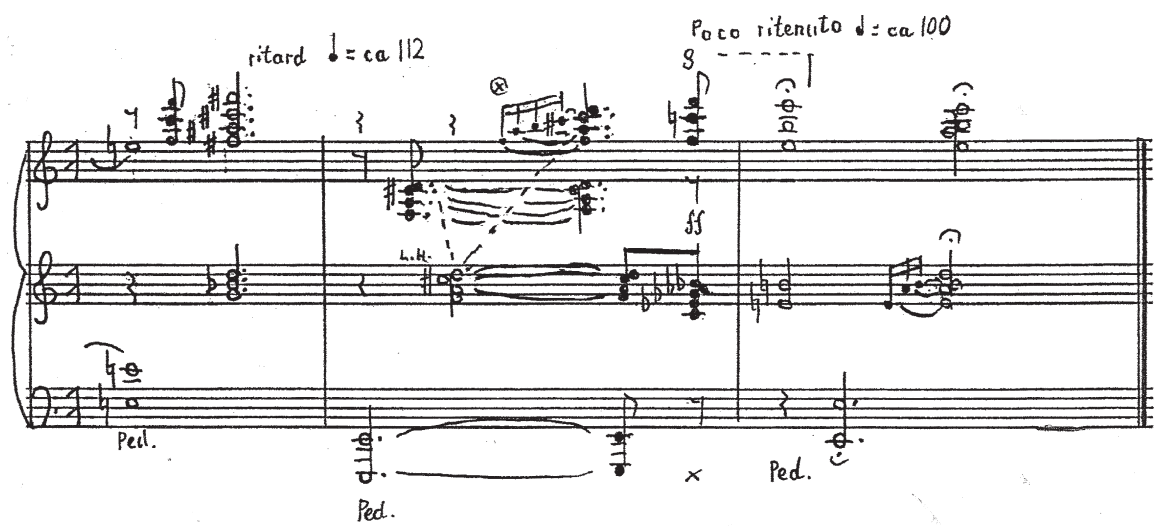

Example 2. Morawetz: Poetic Sketch 3: Storm, bars 86-88 (with the kind permission of Claudia Morawetz)

the opening E-flat of the piece that by the second beat has the enharmonic equivalent of E, F-flat, placed against it.

Possibly some of the harmonic combinations to be found in Morawetz's late piano works not only grew out of his expansion of late Romantic chromaticism but the application of modes other than the standard major and minor. In Moods many of the pianistic fast runs seem to be crafted out of modules that use portions of the major or minor scales but then veer off to a different arrangement regarding tones and semitones. See, for example, the runs that occur in the last system of the first page of the second Mood ("Sample 2," "Four Contrasting Moods," Morawetz 2014).

In the Sketches this deliberate type of experimentation with ordering becomes more evident. Morawetz often combined the tetrachord of one mode with another from a different mode. For example, the lower tetrachord of the right-hand descending scale used in bar 18 of Storm is the recognizable one found in the Phrygian mode. The upper four pitches are a series of whole tones. Another interesting example from the Sketches is the descending right-hand scale beginning on $\mathrm{G}$ and then repeated from $\mathrm{D}$ to be found in bar 11 of the Olympic Sprinter. ${ }^{10}$ Here the upper tetrachord could be analyzed as that of the descending melodic minor mode, while the lower tetrachord would be that of the Lydian mode. Although piano pieces by Debussy do not appear in the documented recitals given by Morawetz, he undoubtedly had analyzed these scores and probably realized the composer's propensity to shift from mode to mode within a piece, a practice subsequently used by other composers in the twentieth century.

Rhythmically Morawetz had made use of changing metres in his earliest works and continued the practice of metric modulation throughout his composing career. Possibly Czech dance rhythms influenced his sense of metre, although in the interview produced by Cornfield (2002), Morawetz denies using

10 This is the last bar that can be viewed on the opening sample page of the piece to be seen at "Sample 5," "Four Contrasting Moods," Morawetz 2014. 
obvious Czech references in his mature, serious works. Nevertheless, Czech dance tunes often use changing groups of two and three beats, for example, 1 , $2,3,1,2,1,2$. In the view of this author, that might have been an influence for the frequent shifting from $3 / 8$ to $4 / 8$ (two plus two) that occurs in the central section of the third Mood. In any case, the piano music of Morawetz is always metred. There are no passages of graphic notation or instructions to the performer to freely interpret a section rhythmically.

The final composition that Morawetz worked on was the Fantasy, the first 100 bars on seven pages available on the website ("Unfinished Work," Morawetz 2014). The page also quotes from the application to the Ontario Arts Council from which Morawetz received funding in 1994 to compose the piece. He stated that after speaking with the Argentinian, Toronto-based pianist Alma Petcherski, he wished to compose a work for piano using the style of the songs sung by the Sephardic Jews. His application includes the comment that, as far as he knew, no concert composition had been based on the Sephardic tradition. ${ }^{11}$

The next question to ask is how much Morawetz knew about Sephardic music. Possibly he realized that no one knows what melodies Sephardic musicians used prior to 1800 or so, as in the application he stated that he was going to use rhythms associated only with Sephardic music. As far as this author can determine, Morawetz did not contact Judith Cohen, a Toronto-based researcher and performer of Sephardic music. In her articles she points out that the rhythms heard in Sephardic music as it is known today were absorbed after the Diaspora from the Turkish and/or Moroccan cultures (see Cohen 2003). Instead of listening to recordings by Cohen's group, Gerineldo, Morawetz probably listened to commercial compilations such as the four CD set, The Sephardic Magen David of Beverly Hills Presents Authentic Sephardic Music. ${ }^{12}$ If that was the case, he would have heard a beautiful florid vocal melody accompanied heterophonically by usually a chordophone or two, sometimes with an underlying pedal note, and various percussive instruments. The latter often produce a rhythm that to Western ears can be grouped as eight eighth notes in a $4 / 4$ metre. From time to time, there can be a dotted rhythm that could be interpreted as a dotted eighth followed by a sixteenth.

Turning to the extant pages of his Fantasy, one can see that indeed those rhythmic patterns seem to be prevalent. As already observed in his late piano works, the opening is written on four staves to deal with all of the gestures that Morawetz wishes the performer to create. These gestures include a downward arpeggiated seventh chord followed by an upward broken ninth chord, containing pitches that he will subsequently use in his practice of "musical prose," transposing them to different degrees with subtle alterations and never bringing back exactly the opening forms. Interestingly, the opening twenty-six bars often have a low pedal note E, possibly suggesting the practice heard in

11 This statement was probably true at the time of the application, as Betty Olivero (b. 1954) had just completed her Sofim (Endings) for piano in 1991, and it was 1999 before Yitzhak Yedid (b. 1971) brought out his recording of Compositions for Solo Piano.

12 Samples can be heard at Desire to Share, www.desiretoshare.com/music/magendavid.htm. 
performances of Sephardic music today. On page 3 , at bar 35 when the $4 / 4$ metre returns after a bar of 2/4, chains of upward sixteenth notes appear that might suggest the florid embellishment used by Sephardic musicians. On page 5, a long right-hand trill on B-flat begins that could also be reminiscent of ululations used by Sephardic singers. Soon on page 7 at bar 81 , very different musical material appears in a 3/4 metre. We have no idea what the composer was going to do with this, as the onslaught of depression prevented the completion of this composition and indeed marked the end of his creative work.

The piano music grew out of the repertoire that Morawetz studied and played. Because he was a skilled pianist, he often devised demanding virtuosic passages for the performer if he felt that these were needed for working with the materials he had selected. Whereas his colleague, John Weinzweig, ventured into using the piano as a percussive instrument and incorporated techniques devised by the American composer Henry Cowell and others in the early twentieth century, Morawetz did not pursue that avenue.

\section{Weinzweig and the Piano}

Unlike Morawetz, John Weinzweig did not come from a privileged household, so his piano lessons began later in life. In fact, he became involved with music through his experiences at the Workmen's Circle Peretz School in Toronto and its summer Camp Yungeveit (Keillor 1994, 6). When his father, a Jewish furrier, became more prosperous, his mother decided in 1927 that John and his younger brother, Morris, should have piano lessons, so for their teacher, she selected Gertrude V. Anderson, who lived just down the street from their home in Toronto.

According to Anderson's handwritten account (1939, author's collection), Weinzweig wrote his first compositions after studying piano for only one year and theory for a few months. She goes on to list compositions that he completed while a student at Harbord Collegiate Institute, which included "an orchestral work, a group of piano pieces, an orchestration entitled 'Scenes on the Volga,' ... a violin concerto and an overture scored for full orchestra" (Beckwith and Cherney 2011, 5). In an interview with the author, Weinzweig admitted that his mind would wander while trying to play a work by Chopin at one of his lessons. Fortunately Anderson was very tolerant of his improvising (Keillor 1994, 7). Although Weinzweig continued to study theory with Anderson, his later piano teacher was George Boyce (Beckwith and Cherney 2011, 6). He completed the Grade X piano and Grade V theory requirements of the Toronto Conservatory of Music (6).

In an interview of 1968, Weinzweig reminisced about his early experiences in music: "Between the ages of 14 and 19 I studied the piano, mandolin, sousaphone, double bass and tenor saxophone (and harmony). I played and conducted school orchestras, dance bands, weddings, lodge meetings and on electioneering trucks for a range of fees between two dollars and a promise. I played Pirates of Penzance, Santa Lucia, Poet and Peasant, Blue Danube, St. 
Louis Blues, Liszt's Hungarian Rhapsodies, Chopin waltzes and Tiger Rag. At age 19 I got serious and decided to become a composer" (Anon. 1968, 9).

Undoubtedly before the age of twenty he had been exposed to and participated in a wide range of music that went beyond the classical corpus. He knew the popular music of the day and became adept at manifestations of early jazz. On the other hand, like Morawetz, he studied as many scores as he could get his hands on at the nearby Toronto Central Library. Although he accompanied a friend in operatic arias, it is unlikely that he tried to reproduce them at the piano, as Morawetz had done at a similar age. He was particularly fond of the works of Wagner but did not have the opportunity to actually hear live performances, as Morawetz had been able to do at Bayreuth.

The early experiences with the piano solidified his later practice of using it as a tool in teaching and composition. However, he never attained a high level of pianistic skills. In fact, his students often had quite negative comments about his performance at the piano. According to Robert Aitken, "The rhythms he would improvise on the piano were derived from jazz but were rarely complex, probably due to his piano playing limitations" (Rea 2011, 93). Gary Hayes recalled, "I can still see him sitting at the piano, stomping his foot and hammering away as he played through sections. He was a terrible pianist, but clearly loved to get a visceral feel for the music" (96). Possibly his limitations at pianoplaying had a bearing on what kinds of material he devised in his piano solos, but he has left us with a number of piano gems.

His first piano solos in his last compositional decade were specifically pedagogical, a new direction in his composing career and one that Morawetz never pursued. It is very difficult to create interesting works for young pianists with limited experience and skill. Weinzweig always set challenges for himself. Possibly there was some prodding from the executive members of the Alliance for New Music Projects, who were always looking for valuable contemporary pedagogical materials, but Weinzweig first accepted this challenge in his Diversions: 4 Pieces for Young Pianists (1994). He assigned enticing titles to each of the four pieces: "Distant Bells," "Gathering Clouds," "Land of Nod," and "Games." It seems that he arranged them in increasing levels of difficulty. The first presents usually two-note dyads in each hand that change at a very slow rate, but their performance needs to be coordinated with the damper pedal. The second presents more activity in both hands and extensive use of changing metres from $5 / 4$ through to $2 / 4$. In the third one, the hands usually alternate playing, but very specific dynamic levels must be followed. Whereas the right hand explores the possibilities inherent in two-note dyads, the left hand uses Ds in two different registers throughout, with only four exceptions. "Games," the longest piece at three pages in the manuscript score, consists of strongly contrasting sections in tempo, mood, and dynamics. Somewhat unusually for Weinzweig in his late works, the opening section returns in exactly its original form, seemingly hearkening back to classical rondo-structure as he sometimes used in some of his earliest divertimentos and in Refrains (1977). After its last appearance, though, the opening gesture of the second section is built on with changes of material and differences of mood and tempo. Accordingly this piece bears resemblances 
to the pieces organized in "events" or "sections" that he composed beginning in 1970 and on until the late 1980 os (Keillor 2011, 121).

His next pedagogical excursion was a set of 7 Piano Duets (2000), a commission from the Canadian Music Centre and the Alliance for Canadian New Music Projects, with funding from the Millennium Funds of the Canada Council and Ontario. Once again he used appealing titles: "Swingin' Blues," "Conversations," "Birds of a Feather," "Go-Train," "Ballerina," "Joie de vivre," and "Ariette." As Beckwith has pointed out, taking rhythmic ideas from the blues became a dominant characteristic of Weinzweig's style after 1960, particularly "the blues mood of the radio crooners" and "the 'swing' of the big radio bands" (Beckwith 2011, 208). Consequently "Swingin' Blues" is almost completely notated in $4 / 4$, the classic jazz metre, with only two bars of $3 / 4$. Pitch fluctuations suggest the variable thirds and sevenths that occur in blues, but it is the prominent use of the rhythmic gesture of dotted eighth followed by a sixteenth that underlines its "swingin" nature. Dialogue between instruments or instrumental groups has been a dominant characteristic of Weinzweig's approach since the early 1940s. In the author's opinion, his application of this principle largely came about with his involvement in providing music for radio dramas (Keillor 2011, 124). In this set of duets, only in the first, fourth, and sixth do primo and secondo play together almost constantly. In the others, he followed the practice that he established in "Conversations," where primo leads off and secondo answers. Only in the last one is that order reversed, with secondo presenting the initial gesture that is then commented upon by primo. Interestingly, perhaps to even things out, in the duets where both pianists play most of the time, secondo leads off.

Of course, those who are familiar with Weinzweig's music will hear similarities with earlier works in his oeuvre, but even so, he searched out further possibilities with that material. A case in point is "Birds of a Feather." In several earlier compositions Weinzweig incorporated notations of birdsong, particularly the Canada bird. ${ }^{13}$ In his choral work, On Wings of Song (1986), the material consisted solely of birdsongs that he heard around his Kearney property (Keillor 1994, 109). The duet includes several different calls, and bird-lovers would enjoy trying to identify those chosen and imitated on the piano.

Netscapes (2000) has the advanced pianist in mind. On the score of Netscapes sent to this author, Weinzweig wrote, "A Divertissement for your nimble fingers." Weinzweig never owned a computer, but in the score he wrote, "I imagined browsing on the internet and discovering a wide variety of music fragments, each with its own sonic profile of sufficient thematic interest requiring no further elaboration. The repeated keyboard fragments conclude with a postscript or cadence, then continue to the next fragment without a pause." From this description one can discern similarities to the works where the materials are ordered as "events," such as Impromptus for Piano: 23 Events (1973).

13 The white-breasted sparrow, whose call sounds like the syllables of "Ca-na-da." See my note in John Weinzweig (278). Louise Murphy incorporated this bird call in Sweet Canada (1923) It was subsequently used by R. Murray Schafer (see Adams 1983, 195) and John Beckwith in Canada Dash, Canada Dot (1967), and by Weinzweig, first in Private Collection (1975). 


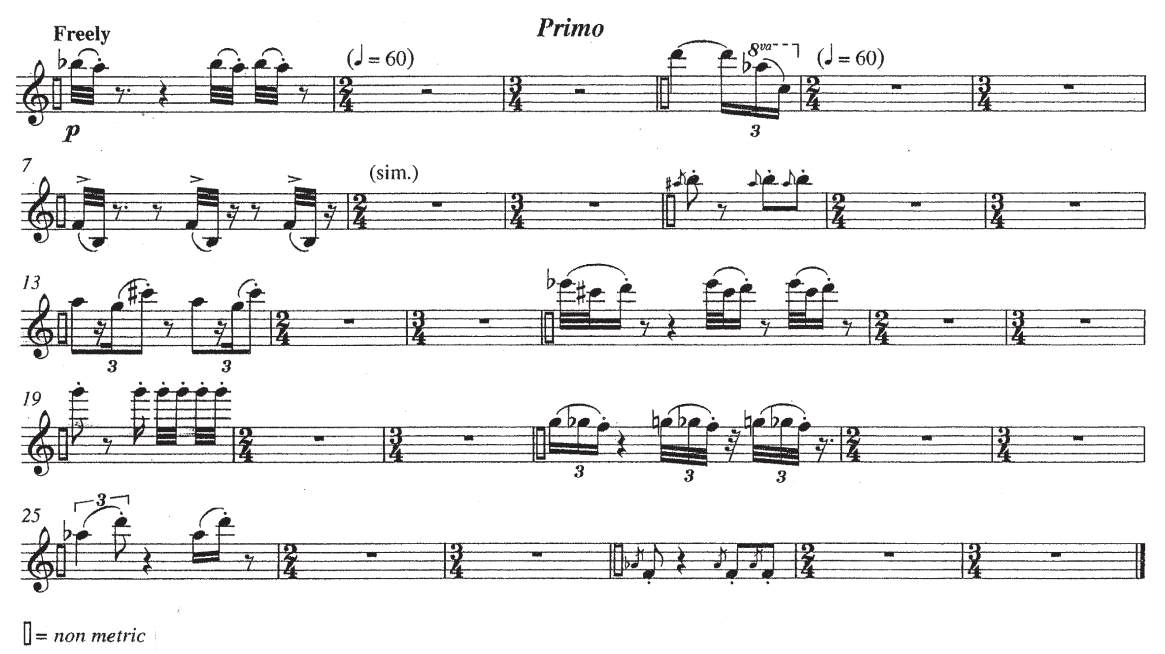

Example 3. Weinzweig: Primo of Birds of a Feather (with the kind permission of Daniel Weinzweig)

In Netscapes the sections are longer than those to be found in the earlier work. In part this is due to the fact that most segments within a section are to be repeated three times. Some have their own cadence to be added after the third rendition.

Each segment bears hallmarks of Weinzweig's typical materials. The opening segment, for instance, has a one-bar announcement gesture that is then repeated with slightly varied intervals and rhythmic patterns. Segments in the first section often remain in one particular register of the keyboard. Yet within this opening section, Weinzweig used almost the whole gamut of the keyboard as he liked to do. As early in his piano writing as Dirgeling (1939), where silent depression of a diminished seventh chord produced harmonics in the resultant sound, Weinzweig had explored expanded possibilities of producing his piano sound world. In Trialogue (1971), the pianist has to play directly on the strings with hands and fingers, use three types of percussion beaters on the strings, and make percussive sounds on different parts of the piano frame (Keillor, 1994, 78). Frequently Weinzweig called upon the pianist to produce wide clusters, using the hand and even forearm, as in Impromptus and Micromotions (1988).

In the first section of Netscapes, Weinzweig introduced a new method for producing clusters, using the knuckles of the right hand over a tritone whitekey expanse. Two lyrical "Interludes" with fluctuating metres of 6/4, 5/4, and 4/4 provided contrast with the percussive nature of many of the gestures used in the first and third main sections of the piece. Each interlude has another Weinzweig hallmark: a changing ostinato idea based on a fluctuating minor and major third that could be considered a "blues" element. The concluding "Postlude" of forty continuous bars mostly has the standard jazz metre of $4 / 4$, with two insertions of 5/4 near the conclusion. The opening texture and rhythm is reminiscent of the very first idea presented, and the left hand stresses the pitch F, also found at the cadence of the first idea. 
Swing Time (2000) has five movements, a faster tempo alternating with a slow one. Many of the gestures used were those to be found in Netscapes but further explored. The process followed seems to be one that Weinzweig first developed when he worked with two- or three-note sets from a twelve-tone row. To that exploration of the pitches involved, he added varying short rhythmic ideas, coming from the world of swing band music. As Aitken has pointed out, "To witness him improvising and in fact composing at the piano you noticed an almost childlike fascination with what he was doing. He seemed to delight in relatively basic melodic and rhythmic combinations" $(2011,351)$.

For his penultimate completed composition, Weinzweig returned to the piano with Playnotes: 8 Pieces for Piano (2002). Once again he chose descriptive titles for each movement, after much consideration, as can be seen on the manuscripts and working sketches for these pieces: "Reflections," "Euphoria," "Shadows," "Quietude," "Presto Pronto," "Jubilation," "Everyday Blues," and "Rush Hour."14 According to his note on the score, these are "arranged in pairs: a slower tempo followed by a faster one. When playing selections only, contrasting tempos are recommended." Each can be considered a musical event, with short rhythmic ideas, often inspired from swing and jazz, being preeminent. Several centre on sonorous techniques that he had discovered and used in earlier compositions, such as the effect of "bleeding clusters or chords" to be found in "Shadows." For Weinzweig, the bleeding cluster consisted of creating an aggregate chord and then the pitches would be gradually removed, usually one-by-one or in groups until only a single-pitch remained (Nolan 2011, 145).

In many ways these pieces can be considered a summary of how Weinzweig came to write for the piano. Textures are generally sparse, with rarely more than three or four notes sounding at one time unless a cluster effect is used. The repetition of short melodic and rhythmic gestures in slight variants forms the basis of his materials. The establishment of a tonal centre comes through either repetition or logical melodic development, usually through semitones. For example, in "Presto Pronto," each hand begins with a triplet sixteenth eighth note figure in contrary motion. The right hand has $\mathrm{D}+\mathrm{D}$-flat $+\mathrm{C}+\mathrm{B}$, and the left hand E-flat + F + F-sharp + G. Gradually working with variants of this figure and intermediary passages of eighth notes, the left hand introduces

14 The manuscript sketches for these "miniatures" indicate alternative titles in brackets and usually the date of composition (folder 61, box 3, John Weinzweig Fonds, MUS 154 [2005-2], Library and Archives Canada, Ottawa).

"Reflections" [Contemplation; Daydream; Memories; Musings] 12 November 2002. Its sketch works on a figure that appears on page 3 of sketches for Netscapes.

"Euphoria" [Happy Dreams; Relaxing] 17 August 2002.

"Shadows [Bleeding Chords; Colours; Prism]. This piece is reminiscent of gestures that Weinzweig wrote out on the verso, third and fourth systems of a sketch for Interlude of Netscapes.

"Presto Pronto" [Hurry Scurry; Hustle Bustle; Don't Stumble] 10 August 2002.

"Quietude" [Musings] 25 November 2002.

"Jubilation" 28 August 2002. This piece incorporates an idea that appeared on the second system of the third page verso of the sketches for Netscapes.

"Everyday Blues" [Longing Blues; Cool, Light; Sunset Blues; Blues] 5 August 2002.

"Rush Hour" 23 August 2002. 


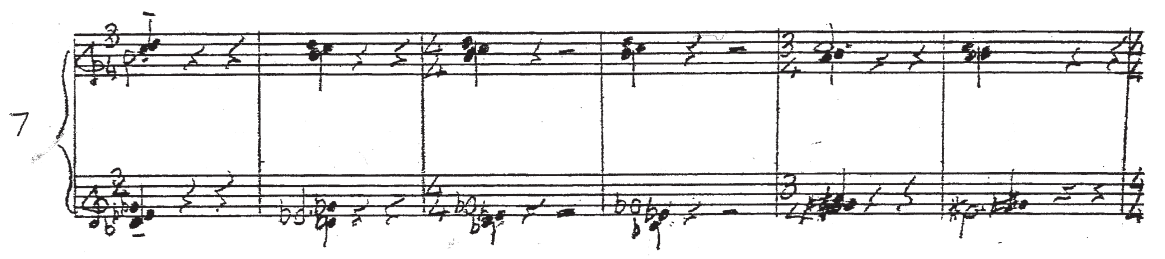

Example 4. Weinzweig: Shadows, bars 7-12 (with the kind permission of Daniel Weinzweig)

B-flat while the right hand takes over the E-flat pitch. As the right hand works through eighth-note material that features A-sharp, the enharmonic equivalent of B-flat, this logically leads the listener to the conclusion. There both hands again have triplet sixteenths followed by an eighth-note figure, but the right hand is D + D-flat $+\mathrm{C}+\mathrm{B}$-flat, while the left hand has F + F-sharp + G + E-flat, forming a satisfying conclusion. Although some of the pieces lack a large number of dynamic signs, "Reflections" and "Everyday Blues" contain a wide range. As Aitken has pointed out, he gave "dynamics a lot of consideration" (2011,360). In performance Weinzweig wanted the dynamic level, and especially the rhythms, to be absolutely precise.

\section{COMPARISON AND CONClusion}

Undoubtedly there are parallels between Morawetz and Weinzweig in addition to being of Jewish heritage and becoming professors at the Faculty of Music, University of Toronto, in 1952. Both developed their professional musical skills largely in Toronto, took piano lessons there, obtained a Bachelor of Music from the University of Toronto, and studied theoretical subjects with some of the same teachers, such as Leo Smith. Both of them felt that they largely had to teach themselves to be composers, although Weinzweig had the opportunity to pursue graduate studies at the Eastman School of Music, considered the foremost school for American composition in the 1930s. However, when Weinzweig discovered the music of Berg and Schoenberg in the Sibley Library there, no one on staff would discuss that music with him (Keillor 1994, 19). Interestingly, Morawetz did play early works by Schoenberg and Berg for his students, but he never felt the need to organize his pitch materials according to serial principles.

This discussion of Morawetz's and Weinzweig's late piano music underlines differences in procedures and the influences that went into how these two composers conceived musical composition. For example, this author heard Weinzweig deriding the Symphonie fantastique of Berlioz, a work that probably Morawetz respected for its innovative orchestration. ${ }^{15}$ Weinzweig welcomed

15 While a student at the University of Toronto, the author had Morawetz and Weinzweig as professors. Morawetz was an inspiration for his ability to recall instantaneously a wide range of musical repertoire and to create effective reductions of complex scores. In analysis class one day, he asked the assembled students which work included in the required text would they like to have analyzed next. We unanimously asked for the section of Stravinsky's Le Sacre du printemps. The next week Morawetz began his presentation on the work, but we could not follow his bar numbers with the version we had. Apparently he had not investigated the tangled publication history of this work, nor 
Morawetz into his circle of composers (Cherney 2011, 59), but at the Faculty their relationship was likely somewhat strained. There is some indication (Morawetz 2014) that Morawetz felt slighted, particularly after having achieved many foreign performances of his works, as he had to wait almost twenty years to be promoted to full professor, even though he had a doctorate when others did not. Also Morawetz was never given a graduate course in composition as part of his teaching duties. ${ }^{16}$ Of course, the atmosphere in North American music faculties just past the mid-twentieth century between the two compositional camps-those who supported serialism and those that did not-did not assist the situation.

As indicated above, Morawetz and Weinzweig early on viewed the piano as their main instrument, both for playing on, and as an aid in working out their compositional ideas. As a result we have wonderful additions to the piano repertoire from both composers. Yet each composer wrote very differently for the instrument, and thus the demands made on the pianist vary considerably. To play Morawetz well, one must have a thorough grounding in Romantic and late Romantic repertoires with the technical skills necessary to play his repertoire, which is all written for the advanced pianist. Overall his piano writing grew out of that heritage, and he really did not ask the pianist to deal with extended techniques. The situation is certainly different for the works by Weinzweig.

On Weinzweig's Piano Concerto, Bruce Mather observes, "This is a highly original work and the piano writing is excellent, even if not many pianists would be interested in playing it" (Beckwith 2011, 215). Few pianists have accepted the challenge because Weinzweig's scores look deceptively easy on the page, although they are a challenge to interpret. The pianist must follow the directions of the composer in order to maintain the momentum. This usually depends on incorporating jazz-like approaches to rhythm and observing the precise dynamic levels indicated by the composer and possibly adding to those already given. After a discussion on how to perform Weinzweig's music at the Centennial Symposium at the University of Toronto in March 2013, Austin Clarkson wrote,

John Weinzweig's later music appears to be a series of disparate gestic/ phonetic shapes that reference everyday happenings and popular music. These are reiterated in modules separated by brief pauses, apparently a stop-start telegraphy, an attenuated hoquetus. If we think of this music as a kind of minimalistic monophony, we overlook the dialectic between the idea of Fortspinnung and its antithesis, which we might call Rückhaltung. Performers (and listeners) must integrate JW's gestic/phonetic shapes with that in mind in order to project the overarching "absolute melody."

\footnotetext{
checked to see that the edition he had used for his analysis was the same as his students'. This experience suggests that the work had not been crucial in his compositional influences. The opposite was true for Weinzweig. Le Sacre was the first musical composition that he had ever had to analyze fully and remained for him always an inspiration (Keillor 1994, 18).

16 It has been frequently pointed out how influential Weinzweig has been as a teacher of composition in Canada (Rea 2011, 75), but many who had Morawetz as a composition teacher speak warmly of his guidance, including Tomas Dusatko, Larysa Kuzmenko, Bruce Mather, and Srul Irving Glick.
} 
The categories of incoherence must be as carefully characterized as the categories of coherence. The disparities among the objects that make up a piece must be articulated as clearly as their similarities. The performer/ listener must internalize the gestic/phonetic character of the shapes in order to build up the total picture of the composition's idea. This creates a "virtual polyphony," a global "concord of sound." (Personal communication to author)

In other words, the pianist cannot depend on familiarity with the idioms of earlier piano repertoire to carry the performance and the listener along. Instead the performer must be very conscious about the longer line that Weinzweig has provided. Whereas in the standard repertoire, pianists seldom pay attention to the longer line because they become so accustomed to playing certain figurations, in performing Weinzweig those same pianists have to search out and understand his dialectical argument in order to create a successful rendition.

\section{REFERENCES}

Adams, Stephen. 1983. R. Murray Schafer. Toronto: University of Toronto Press. Aitken, Robert. 2011. "How to Play Weinzweig." In Beckwith and Cherney, Weinzweig, 149-364.

Anon. 1968. "John Weinzweig, a Portrait." Musicanada 9 (March): 8-9.

Beckwith, John. 2006. In Search of Alberto Guerrero. Waterloo, ON: Wilfrid Laurier University Press.

—. 2011. "Jazz Swing' and 'Jazz Blues." In Beckwith and Cherney, Weinzweig, 207-24.

- 2012. Unheard Of: Memoirs of a Canadian Composer. Waterloo, ON: Wilfrid Laurier University Press.

Beckwith, John, and Brian Cherney, eds. 2011. Weinzweig: Essays on His Life and Music. Waterloo, ON: Wilfrid Laurier University Press.

Cohen, Judith. 2003. "Sephardic Song." Midstream Magazine (July/August 2003), https://archive.today/fVQRw.

Cornfield, Eitan. 2002. "Morawetz Documentary." In Oskar Morawetz: Canadian Composers Portraits. Centrediscs CMCCD 8702.

Gillmor, Alan. 2011. "In His Own Words." In Beckwith and Cherney, Weinzweig, 267-86.

Keillor, Elaine. 1994. John Weinzweig and His Music: The Radical Romantic of Canada. Metuchen, NJ: Scarecrow.

_.2011. "Music for Radio and Film." In Beckwith and Cherney, Weinzweig, 103-30.

MacMillan, Keith, and John Beckwith. 1975. Contemporary Canadian Composers. Toronto: Oxford University Press.

Mitchell, Donald. 1986. Gustav Mahler, Songs and Symphonies of Life and Death: Interpretations and Annotations. Oakland: University of California Press.

Morawetz, Oskar. 1985. Four Contrasting Moods. Canadian Music Centre, Mi 2110 M831fo.

_. 1991. Five Poetic Sketches. Canadian Music Centre, Mi 2110 M831 fi. 
. 1995. Fantasy for Piano. Incomplete. "Unfinished Work," Oskar Morawetz, http://www.oskarmorawetz.com/Tabs/TabMusician/Unfinished.php. - 2014. Website. http://www.oskarmorawetz.com.

Nolan, Catherine. 2011. "The First Canadian Serialist." In Beckwith and Cherney, Weinzweig, 131-50.

Rea, John. 2011. "The Teacher." In Beckwith and Cherney, Weinzweig, 75-102. Sallis, Friedemann. 2003. "Deconstructing the Local: The Aesthetic Space and Geographic Place of Oskar Morawetz's String Quartet No. 5 'A Tribute to Wolfgang Amadeus Mozart' (1991)." Canadian University Music Review 24 (1): 7-29, http://id.erudit.org/iderudit/1014669ar.

Rapoport, Paul. 1994. "The Piano Music of Talivaldis Kenins." SoundNotes $7: 18-24$.

Weinzweig, John. 2000. 7 Piano Duets. Canadian Music Centre ms. . 2013. Complete Piano Works, ed. Brian McDonagh. Toronto: Plangere.

\begin{abstract}
Oskar Morawetz and John Weinzweig were colleagues of Carl Morey at the Faculty of Music, University of Toronto. Each composed considerable piano music throughout his compositional career. In this article, the author examines the late piano compositions of Morawetz and Weinzweig, comparing approaches to the instrument, and how those approaches were reflected musically in this group of late compositions. Because Morawetz based his approach on the late Romantic piano compositions with which he was familiar, pianists do not encounter extended techniques in his works. Weinzweig, on the other hand, makes new demands upon the performer to bring across his "disparate gestic/phonetic shapes."
\end{abstract}

\title{
RÉSUMÉ
}

Oskar Morawetz et John Weinzweig étaient des collègues de Carl Morey à la Faculté de musique de l'Université de Toronto. Tout deux ont composé un nombre considérable d'œuvres pour piano pendant leur carrière de compositeurs. Dans cet article, l'auteur examine les dernières compositions pour piano de Morawetz et Weinzweig en les comparant du point de vue de leur approche de l'instrument et des conséquences musicales de ces approches. Puisque l'approche de Morawetz est basée sur sa connaissance de la musique romantique pour piano, les pianistes ne rencontrent pas dans son œuvre de grands défis techniques. En comparaison, la musique de Weinzweig amène les pianistes à innover au niveau technique afin de réaliser ses formes sonores liées à une "gestuelle erratique». 